\title{
A History of Erotic Philosophy
}

\author{
Alan Soble
}

\begin{abstract}
The most striking distinction between the erotic life of antiquity and our own ... [is] that the ancients laid the stress upon the instinct itself, whereas we emphasize its object. The ancients glorified the instinct and were prepared on its account to honour even an inferior object; while we despise the instinctual activity in itself, and find excuses for it only in the merits of the object.
\end{abstract}

Sigmund Freud, Three Essays on the Theory of Sexuality (note, 1910)

In the last quarter of the 20th Century a distinct subarea of philosophy arose. Professional books and articles on the philosophy of sex were published during this period. University courses devoted to the topic proliferated. ${ }^{1}$ Questions addressed by academic philosophers included the ontological and analytic, for example, "What is sexual activity?" or "How to define 'sex act'?" -- an issue that the public discussed, too, after President William Clinton denied that he had "sexual relations with that woman," Monica Lewinsky. Academic philosophers also addressed normative or evaluative questions, such as "What is natural human sexuality?" (in contrast to "perverted" sexuality) and "What is morally right or permissible sexual behavior?" This new focus of study emerged partially with second-wave feminism's criticism of the politics of heterosexuality and sex discrimination and with the slowly growing legal and social acceptance (including network television) of minority sexualities. Scholars working within the phenomenological, existentialist, evolutionary, conservative, Marxist, liberal, feminist, and diverse theological traditions have written much about the metaphysics and ethics of sexuality, although the philosophy of sex remains eclectic and interdisciplinary, not wedded to any particular ideological perspective.

In addition to studying specific ontological and moral issues, scholars can also approach the philosophy of sex historically. In this project, they explicate the writings of significant figures from the past, fashioning into a coherent whole what might resemble a loose set of scattered claims. Or they investigate the thought of a philosopher to discern characteristics of the period or culture in which he or she wrote. Or they use this history as a mirror (or even as a lamp) to see contemporary practices and ideas more clearly or freshly. Another task is tracing an argument, theme, or problem (e.g., the nature of sexual desire or arousal) through a series of thinkers, showing how it stays the same and how it gets modified over the centuries. Philosophers of sexuality have concentrated, so far, on definitional and evaluative matters. The history of the philosophy of sex is the least developed part of the field.

Human sexuality is, of course, a topic that is endlessly discussed and over which people argue ad libitum et nauseum, not only at scholarly conferences but also in the local tavern or coffee shop. The subject is not owned by professional philosophers. Indeed, the glossy volumes on the shelves of mall bookstores are written by ordinary people, amateurs, and popularizers of evolutionary, psychological, sociological, and theological thought on sexuality. What is the difference, if one exists, between professional philosophical examination of sexuality and your mother's "philosophy" of sex or the "philosophy" of sex of the corner grocer? One view is that the spirit of Socrates (ca. 469-399 BCE) informs genuinely philosophical thinking about sex: 
emphasizing precision, being willing to challenge received opinion, and persistently searching for elusive, hidden truths. But it must be admitted that some non-philosophers manifest this spirit as well, and that it is not always exhibited by those traditionally called "philosophers" or those formally trained in philosophy.

My presentation in this essay of a history of philosophizing about sexuality, by focusing on writers identified as canonical philosophers, is not meant to slight the contributions of other disciplines or to imply that what this small group of writers produced is more illuminating. The problem might be the reverse: "Ask if it's sex or power that makes the world go round, and you can keep the pub open long after licensing hours; in a philosophy seminar, the same question is likely to produce only rolled eyes" (Appiah, 1997, p. 5). While I am exploring the history of the philosophy of sex, I attempt to show that not only philosophers but also their compatriots in other fields have said interesting things about sex. For example, in 1929 James Thurber (18941961) and E. B. White (1899-1985) wrote a small book (Is Sex Necessary?), a parody of the new, early-20th-century psychology of sex. We can surely learn from this book, even though it was designed to amuse. A man delays marriage, Thurber and White observe, because he has

\footnotetext{
the suspicion that if he waited twenty-four hours, or possibly less, he would likely find a lady even more ideally suited to his taste than his fiancée. Every man entertained such a suspicion. Entertained it royally. He was greatly strengthened in his belief by the fact that he kept catching a fleeting glimpse of this imaginary person $\square$ in restaurants, in stores, in trains. To deny the possibility of her existence would be, he felt, to do a grave injustice to her, to himself, and to his fiancée. (1975, pp. 96-99)
}

Thurber and White are not canonical philosophers, but Søren Kierkegaard (1813-1855) is. In Fear and Trembling (1983, p. 91), nearly a hundred years before Thurber and White, he had similarly written:

\begin{abstract}
A man is bound to one girl whom he once loved or perhaps never loved properly, for he has seen another girl who is the ideal. A man makes a mistake in life; it was the right street but the wrong house, for directly across the street on the second floor lives the ideal $\square$ this is supposed to be a subject for poetry. A lover has made a mistake, he has seen the beloved by artificial light and thought she had dark hair, but look, on close scrutiny she is a blonde $\square$ but her sister is the ideal. This is supposed to be a subject for poetry. In my opinion, any man like that is an impudent young pup who can be unbearable enough in life but ought to be hissed off stage.
\end{abstract}

Where is the difference in their "philosophies" or their approach? Perhaps only that Thurber and White make us laugh at ourselves, while Kierkegaard, the solemn Christian, scorns our wayward tendencies.

Thurber and White also broach a perennial conundrum, the difference, if any, between sexually desiring someone and loving him or her:

At a certain point in every person's amours, the question arises: "Am I in love, or am I merely inflamed by passion?" It is a disturbing question. Usually it arises at some inopportune moment: at the start of a letter, in the middle of an embrace, at the end of a day in the country. If the person could supply a direct, simple, positive answer -- if he could say convincingly, "I am in love," or, 
"This is not love, this is passion" -- he would spare himself many hours of mental discomfort. Almost nobody can arrive at so simple a reply. (1975, p. 62)

Among plenty of other scholars, the contemporary philosopher J. Martin Stafford takes on this challenge (but humorlessly), contrasting, with a "simple reply," passion and love: love is a special affection, involves acts of prolonged care and concern, and includes wanting to spend quality time with (and only with) the beloved, while sexual desire is merely an appetite that demands satisfaction, at any place and time, and implies nothing about good will toward other people (1995, p. 58; see Lesser, 1980). Perhaps this easy answer is right, even though Thurber and White are concerned not with conceptual analysis or definitions, but with the phenomenal feels of love and sexual desire (which are, they suggest, often indistinguishable). Some philosophers will also wonder whether sexual desire might have the ability to generate the benevolence that is usually associated with love, and will ask whether it is really true that love by its nature is more constant and exclusive than sexual desire (Soble, 1990).

One more example. Iris Murdoch was formally trained as a philosopher, wrote some straight philosophy at the start of her career, and then turned to the novel, where she was a huge success. Should Murdoch be included among the canonical philosophers of sex? Probably, even though this permits other novelists, for example Philip Roth and Doris Lessing, to enter that elite group, if only because Murdoch's novels are especially philosophical. Look at a passage in The Black Prince (1974, pp. 216-17), which contains some reflections of her protagonist, Bradley Pearson (a 60 -ish intellectual, head-over-heels in love, or lust, with a girl forty years his junior):

\begin{abstract}
The foreverness of real love is one of the reasons why even unrequited love is a source of joy. The human soul craves for the eternal of which, apart from certain rare mysteries of religion, only love and art can give a glimpse. ... Love brings with it also a vision of selflessness. How right Plato was to think that, embracing a lovely boy, he was on the road to the Good. I say a vision of selflessness, because our mixed nature readily degrades the purity of any aspiration. But such insight, even intermittent, even momentary, is a privilege and can be of permanent value because of the intensity with which it visits us.... Why cannot this release from self provide a foothold in a new place which we can then colonize and enlarge until at last we will all that is not ourselves? That was Plato's dream.
\end{abstract}

The lesson is that we would not do badly by paying some attention to literature as we explore the history of the philosophy of sex. The psychological issue raised by Murdoch $\square$ has her protagonist fallen victim to gross rationalization in creating a high justification for his impossible attachment? $\square$ we can bequeath to his psychoanalyst.

\title{
The Ancient Greeks
}

Although philosophical discussion of sexuality, narrow-construed, in the West began with Plato (427-347 BCE), the poet Sappho (ca. 610-580 BCE), for reasons I've explained, should not be slighted. Her ideas re-appear in later canonical philosophers:

When I behold thee

Even a moment; 
Utterance leaves me;

My tongue is useless;

A subtle fire

Runs through my body;

My eyes are sightless,

And my ears ringing;

I flush with fever,

And a strong trembling

Lays hold upon me;

Paler than grass am I,

Half dead for madness.

(Carman, 1904, fragment VI)

Sappho is tongued-tied, made catatonic by eros, driven crazy by a glimpse of Beauty. We come across this theme often in the history of the philosophy of sex. Eros perennially and ubiquitously causes irrational behavior. Why did a U.S. president slink around the White House in search of sexual experiences? Why did beautiful Helen take up with handsome Paris, leaving family, child, and husband? (Or was she seduced, or abducted? See Homer, Iliad, bk. 3.) Why did Murdoch's Bradley Pearson, although not tongue-tied by eros, fall to his knees, kissing the rug upon which his young angel had recently stood?

Plato's dialogue Symposium examines eros, which he defined as the passion to possess the good and beautiful. The Symposium is provocative and rich, an indispensable foundation for studying the philosophy of sex. Although in large measure a great pagan defender of eros, Plato was not always kind to the sexual impulse. His writings contain the roots of the later Christian antipathy to sexuality. For example, the distinction Plato makes in the dialogue Symposium between crude (or vulgar) eros and heavenly (or spiritual) eros, first mentioned by Pausanias (who was willing, in Freud's words [see the epigraph], to "honor even an inferior object"), and embellished by the priestess Diotima (who was not willing to do so), encourages us to relinquish sexual acts in personal relationships and focus, instead, on morally and intellectually improving ourselves and our partners. In contrast to vulgar eros, heavenly eros is free from wantonness, lust, or lewdness (Symp. 181c-181d, 185c, 209b-210c). In heavenly eros, "the lover and his [mentally beautiful] loved one ... make virtue their central concern." In Plato's Republic (403a403b), Socrates tells Glaucon that in "the right kind of love ... sexual pleasure mustn't come into it, ... if they are to love and be loved in the right way." The same rejection of sexual activity is expressed by Plato in his complex dialogue Phaedrus (256b-256c), in which his protagonist, Socrates, insists that a pair of genuine lovers pursue virtue. Only when overcome by weakness of the will (akrasia) or disinhibited by a cup of wine will they engage in sex:

If the victory goes to the better elements in both their minds, which lead them to follow the assigned regimen of philosophy, their life here below is one of bliss... . They are modest and fully in control of themselves. .. . If, on the other hand, they adopt a lower way of living, with ambition in place of philosophy, then pretty soon when they are careless because they have been drinking or for some other reason, the pair's undisciplined horses will catch their souls off guard and together bring them to commit that act which ordinary people would take to be the happiest choice of all; and when they have consummated it once, they go on doing this for the rest of their lives, but sparingly, since they have not approved of what they are doing with their whole minds. 
Knowledge and excellence should be the goal, not fleeting and distracting physical gratification. Plato, in both Symposium and Phaedrus, praises male-male love or friendship, and his objection to male-male sexuality in Phaedrus seems not to be grounded in its unnaturalness. Instead, any sexuality is less valuable than pursuing virtue. The children of sexual intercourse do not have the substance, and the immortality, of the children of intellectual discourse. Christian clerics later scorned women and marriage for much the same reason.

Plato worried about sexuality also because he was sensitive to its links with power and autonomy. His thoughts about sex eventually become central issues in the political and medical discussion of sexuality in the 20th Century (Gould, 2006; Price, 1989; Santas, 1988; Soble, 1996, pp. 146-148). Plato bemoans the powerful governing influence and even, at times, the absolute sovereignty that pursuing sexual pleasure can have on a person's actions and life. We become slaves to passion and subservient to others, a distinct threat to freedom and thus the happy life. In the Symposium (183b) Pausanias points out, "In the pursuit of his love . . the lover [may] do many strange things. ... He may pray, and entreat, and supplicate, and swear, and lie on a mat at the door, and endure a slavery worse than that of any slave." Socrates (Phaedrus 252a) similarly observes that

the soul of the lover will never forsake his beautiful one, whom he esteems above all; . . . and he thinks nothing of the neglect and loss of his property; the rules and proprieties of life, on which he formerly prided himself, he now despises, and [he] is ready to sleep like a servant, wherever he is allowed, as near as he can to his desired one, who is the object of his worship.

We can laugh at the adolescent antics, inspired by eros (Becky as Beauty), portrayed in Mark Twain's (1835-1910) Tom Sawyer, or in Giuseppe Tornatore's 1988 film "Cinema Paradiso." And we can sardonically acknowledge that American television plays the power of adulterous sexual passion for all it is worth. Yet the compulsive, destructive desire (Tadzio as Beauty) in Thomas Mann's (1875-1955) Death in Venice is sobering.

Aristotle (384-322 BCE) meditates at great length in his Nicomachean Ethics (books 8 and 9) about philia, or friendship-love, arguing that genuine friends seek the good for each other and improve each other's virtue. Given his interest in moral-psychological relationships, that Aristotle said little about sexuality is surprising. Several passages in his texts, though, are noteworthy (Sihvola, 2002). Aristotle understands sexual desire as an appetite, as analogous to the appetites for food and drink. Others in the history of the philosophy (Augustine and Kant) also conflated sex, eating, and drinking as the same kind of thing, animal appetites. After the Greeks, many philosophers and theologians similarly embraced a view of human sexuality that put it on the disreputable material side in the divide between mind and flesh. But others, as we shall see, disagreed.

Aristotle is also well known for his ethics of moderation. The virtue of temperance is concerned with, among other things, the control of the appetites for food, drink, and sex (Geach, 1977, pp. 131-149; Halwani, 2007). Without reason's guidance, satisfying the appetites can be harmful. Excessive attention to desire is bestial and degrading, because desire belongs to humans 
not qua a rational being but qua animal. Temperant people discover the "mean" between excess and deficit in the satisfaction of appetite, avoiding both gluttony and starvation. But Aristotle claims, "mistaking on the side of deficiency as regards [sexual] pleasure, and taking less than the proper amount of delight in them, does not occur often." "Such insensitivity is not human" (NE 1119a6-7). Aristotle, that is, worries more about virtue being undermined by too much sexual desire and activity than by too little sexual desire and activity. Plato's concerns about sexuality undermining autonomy and happiness here bear fruit. Indeed, abstaining from sex, far from being a deficit-violation of moderation, eventually becomes the holy virtue of chastity in Christianity. (In the late 20th Century, the American Psychiatric Association reversed this view, proclaiming "hypoactive sexual desire" a mental disorder [DSM-IV 302.71]. But not "hyperactive sexual desire" $\square$ except for a short-lived flirtation with "sexual addiction" in DSMIII-R [1980, p. 296].)

\section{Medieval Theology}

After the ancients, St. Augustine (354-430) made a lasting impact on the philosophy of sex, so his writings deserve sustained attention. As Plato did, Augustine bemoaned the threat posed to individual peace and self-mastery by sexuality: "[Sexual] lust not only takes possession of the whole body and outward members, but also makes itself felt within. . . . So possessing ... is this pleasure, that at the moment of time in which it is consummated, all mental activity is suspended" (City of God, bk. 14, chap. 16). As the Yiddish joke has it, when the penis steht, the brain goes out the window (or "when the penis is hard, the brains are soft"; Silverstein, 1984, p. 35). Only by the grace of God, says Augustine, can we control our sexuality (Confessions, bk. 10, chap. 29). Augustine has often been the sexual liberal's whipping boy, but not without good reason. Consider this piece of "sex negativity":

A man turns to good use the evil of concupiscence ... when he bridles and restrains its rage ... and never relaxes his hold upon it except when intent on offspring, and then controls and applies it to the carnal generation of children ... not to the subjection of the spirit to the flesh in a sordid servitude. (On Marriage and Concupiscence, bk. 1, chap. 9)

Further, it was Augustine who notoriously wrote about married sexual activity carried out only for pleasure that in these acts the wife is the man's harlot and the man is the wife's adulterous lover (OM, bk. 1, chap. 17).

How did Augustine arrive at his philosophy? We must examine it in the context of the late 4th and early 5th centuries, when three Christian schools of thought existed. First, the rightwing extremism of St. Jerome (340/42-420 BCE; educated in Rome, became an ascetic hermit in the Holy Land, and produced the Vulgate Bible). Second, the left-wing, even radical, disciples of Pelagius (354-ca. 420/440): Julian, Bishop of Eclanum (386-455), and the monk Jovinian (died ca. 406), who was excommunicated by Siricius (334-399) in part for arguing that marriage was as holy as chastity and that Mary, in giving birth to Jesus, lost her virginity. Third, the moderates, Augustine and St. Ambrose (337/340-397), Bishop of Milan, who baptized Augustine in 387 (Clark, 1986, 1996; Pagels, 1988; Ranke-Heinemann, 1990). 
The matter under dispute was not: Did Adam and Eve have sexual relations before the Fall? The consensus, based on Genesis's silence, was "no." Instead, a sophisticated hypothetical question was hotly debated: if Adam and Eve had not fallen, would they have had sex in Eden? Or (nearly equivalently) if Adam and Eve had stayed longer in Eden, would they eventually have engaged in sex? And, if they would have engaged in sex, what would their sexual relations have been like? The theological methodology presupposed by all parties assumed that in order to fashion a Christian sexual ethics, one must understand the pre-Fall (prelapsarian) sexuality of Adam and Eve, for they were in the original, ideal state of humanity. What humans living after the Fall should do is emulate Adam and Eve.

Jerome argued that had Adam and Eve not fallen, they never would have had sex: all sexuality results from the Fall, infected by man's corrupt postlapsarian nature. Sex was not part of God's plan for humans. Ideally, then, we should abstain. Agreeing with St. Paul's (ca. 5-64) epistle 1 Corinthians 7, Jerome did not fear the disappearance of mundane humans, who in God's script are destined to disappear anyway. For Jerome, the good of postlapsarian marriage was that it produced virgins for the Church: "Virginity is to marriage what fruit is to the tree" (Against Jovinian; Schaff, 1892, p. 347). Adam and Eve would not have engaged in sex in Eden because they were immortal; there was no need for replacement. The commandment in Genesis 1:28, "Be fruitful and increase in number," which God had issued to the animals (1:22), meant something else, according to Jerome, when God proclaimed it to Adam and Eve: be spiritually fruitful and increase your virtue.

Augustine agreed with Jerome that Genesis 1:28 partly meant that Adam and Eve should be spiritually fruitful (Clark, 1986, p. 149), perhaps in Plato's sense. But Augustine also thought that God wanted Adam and Eve to have sex and children in Eden (COG, bk. 14, chap. 21). He was not concerned that immortal parents bearing immortal children bearing immortal children would cause population or environmental problems for the infinite riches of Paradise. (Nor did Paul VI [1897-1955] fear this when he reiterated the Catholic prohibition of contraception is his 1968 encyclical "Humanae vitae.") Besides, why did God create Eve? As Mark Twain (2000) pondered, in effect, "Why not another guy with whom Adam could shoot hoops?" Augustine saw the obvious implications of God's making Adam and Eve, not Adam and Steve. Eve was created not only to be Adam's companion but also for human procreation. (A really smart God, though, would have given her a hook shot in addition to a uterus.)

Augustine, then, argued against Jerome that prelapsarian Adam and Eve would have had sex. God intended sex to exist in the ideal state and not only in our corrupt postlapsarian state. What emerged after the Fall was not sexuality itself but spiritually diseased sexuality, even the sexuality that occurs in marriage. The driving, enslaving nature of postlapsarian sexuality, its demand for pleasure and the frustrations that accompany failure are, for Augustine, part of the punishment that Adam and Eve (and all humanity) undergo for disobeying God. Augustine gives us a taste of this damnation from his own life:

I came to Carthage, where a cauldron of illicit loves ... boiled around me. I was not yet in love, but I was in love with love. . . . My longing then was to love and to be loved, but most when I obtained the enjoyment of the body of the person who loved me. Thus I polluted the stream of 
friendship with the filth of unclean desire and sullied its limpidity with the hell of lust. ... I did fall in love, simply from wanting to. ... I was loved, and our love came to the bond of consummation: I wore my chains with bliss but with torment too, for I was scourged with the red hot rods of jealousy, with suspicions and fears and tempers and quarrels. (Conf., bk. 3, chap. 1)

Augustine thought that eventually people should refrain from sex and procreation, not right after the Fall but after the proper number of saints had come into existence, which Augustine thought had happened by the time of Christ. Unlike Jerome, Augustine had to explain Adam and Eve's not having sex before the Fall. He supposed they did not have enough time, eating the forbidden fruit too soon after being created. And notice that God's command for them to be fruitful did not specify any particular time for its fulfillment.

The important result of the Fall was that flesh became ascendant over the will. The flesh rebels against human spirit the way Adam and Eve had rebelled against God. One of Augustine's examples of the victory of rebellious flesh is that men often cannot get erections when they want one, which is disastrous because they then burn with desire; and men often get erections when they do not want one, and are embarrassed by their organ's uncontrollability (COG, bk. 14, chap. 16; OM, bk. 1, chap. 7). Echoing Plato's worry about autonomy, Augustine bemoans the "novel disturbance of their disobedient flesh" (COG, bk. 13, chap. 13) as a source of shame: we realize we cannot control our bodies. ED is not a psychiatric or medical, but a spiritual, disorder.

Augustine's battle with the Pelagians required more energy. Julian agreed that pre-Fall Adam and Eve would have had sex. But he painted a different (and wholesome, from a modern perspective) picture of their mutual sexual desire: it was innocent, divinely blessed, and the "vital fire" of their relationship (Pagels, 1988, p. 141). Adam and Eve would have rejoiced in both procreation and the pleasures of sex. For Julian, what happens to sexuality after the Fall is not that it comes into existence (Jerome) or that it becomes corrupt concupiscence (Augustine), but that it is troubled with what troubles us today: adultery, promiscuity, prostitution. Julian believed that sexual acts should be confined to faithful, heterosexual marriage (as in prelapsarian Adam and Eve) and rejects other sexualities. Within marriage, though, sex may be, without guilt and reservation, as exciting as the spouses could make it. His conclusion might have been inspired by St. Paul's pastoral advice that conjugal sexuality should be as gratifying as possible in order to succeed as a "remedy against sin" (1 Cor. 7:5), for example, to nip adultery in the bud. (In John Milton's Paradise Lost, the sexual relations between Adam and Eve were so blissful [2000, bk. IV, line 509] that the Devil "with jealous leer malign Eyed them" as they were "imparadised in one another's arms" [503-505].)

Not so Augustine. Before the Fall, mind is in control. The operation of the sexual organs would have been voluntary, Adam's penis erecting from his willful (God-like) command for it to rise, as if he were lifting an arm (COG, bk. 14, chap. 16). Adam never suffered from Masters and Johnson's sexual dysfunctions. But he would not have erected by seeing Eve's body or smelling her (COG, bk. 14, chap. 10). Sex in Eden would have known no arousing teasing, no conjugal seduction, no dancing to get in the mood:

Away ... with the thought, that before there was any sin, there should already have been 
committed ... the very sin which our Lord warns us against ... : "Whosoever looks on a woman to lust after her, has committed adultery with her already in his heart." [Matthew 5:28] As happy . . . as were these our first parents, who were agitated by no mental perturbations, and annoyed by no bodily discomforts, so happy should the whole human race have been, had they not introduced that evil which they have transmitted to their posterity. (COG, bk. 14, chap. 26)

Because prelapsarian sex occurs with a tranquil mind, controlled by the will, "those organs would have been moved ... without passion or the pricklings of allurement" (COG, bk. 14, chap. 26). Passion was absent, so the excitement and pleasures of sex (as postlapsarian humans know them) would also be absent. Yes, prelapsarian Adam and Eve would have had sex, by deciding out of love for God to fulfill His command to multiply. (Like thinking about the Queen and doing it for the glory of the empire.) But prelapsarian sex would have been only as pleasurable as any other voluntary movement of the body $\square$ a handshake or hug. No ecstatic "Oh, God!" in Eden.

Augustine's philosophy of sex is explained by his account of prelapsarian sexuality, which provides the model that humans should emulate: sex must be confined to marriage, its sole purpose is procreation, and spouses must not seek sexual pleasure for its own sake. Augustine was indebted to Clement of Alexandria (ca. 150-215), who thought (the "Alexandrian Rule") that sexual acts in marriage were virtuous only if done for procreation (Pagels, 1988, p. 29, citing Stromata 3:57-58). Married couples should even minimize the pleasure that accompanies sex (say, by keeping their clothes on, turning out the lights, and getting the act over with as quickly as possible). Consistently, Augustine denounced contraception. If conception is prevented "by wrong desire or evil appliance," spouses "are really not" husband and wife. Their "criminal conduct" in blocking conception (or aborting a fetus) means "they have not come together so much by holy wedlock as by abominable debauchery" (OM, bk. 1, chap. 17). Given Augustine's conflation of sex and other bodily functions, his criticism of somatic pleasure was general. As a bishop, he was susceptible to lustful thoughts and dreams (Conf., bk. 10, chap. 30); he wrung his hands over pleasures of eating, because he was caught by food in "the snare of concupiscence" (Conf. 10.31); and he was even haunted by the pleasure of hearing beautiful music (Conf., bk. 10, chaps. 33-34). The lure of Jerome's asceticism was not lost on Augustine.

A slightly less negative account of sexuality was elaborated by the theologian St. Thomas Aquinas (1224/25-1274). Tutored by Albertus Magnus (1206?-1280), who also merged Aristotle with Christianity, Aquinas formulated in the mid-13th Century a Natural Law theory of sexuality, in his stupendous Summa theologiae, which became the authoritative foundation of Catholic teaching (by "Aeterni patris," Pope Leo XIII's 1879 encyclical). Heterosexual coitus results from a natural inclination implanted by God and in the act the sexual organs fulfill their natural, God-designed purpose (Summa contra gentiles, bk. III, pt., chap. 126). Aquinas concedes that sexual pleasure is good because God created it. But sexual pleasure, like everything God creates, has its purpose and rightful use. (Aquinas's teleological, Aristotelian ontology is like the evolutionary view, now discredited, that every part of a biological organism must have resulted from natural selection, that is, was advantageous for survival and reproduction.) Sexual pleasure was planned by God to accompany sexual acts that contribute to His ongoing work of creation. Aquinas was replying, in advance, to the playwright Arthur 
Miller's (1915-2005) joke about Augustine's description of Adam and Eve in Eden:

Eve is bent over from the waist, examining ... a turtle. [Adam's] attention is caught by her raised buttocks, and he approaches, halts, and stares $\square$ then looks off, puzzled by an idea he can't quite form in his mind. Giving it up, he asks ... "You want to play volleyball?" (1973, p. 18)

By postulating that humans, like animals, have a natural inclination for intercourse, Aquinas overcomes the problem $\square$ would Adam and Eve's willingness to obey God's command to be fruitful, in the absence of the sexual pleasure of a natural inclination, be sufficient motive for them to engage in procreative sexual activity? And how would they know what to do?

Still, for Aquinas, seeking sexual pleasure is not sinful only if pursued during conjugal sexual acts that are procreative in form, otherwise the sexual organs and the pleasure are being misused in a way inconsistent with God's plan. Aquinas argues in part for his view about the nature of human sexuality on the basis of the sexuality of lower animals, especially monogamous birds (SCG, bk. III, pt. 2, chap. 122, §6). Perhaps he should have taken a better look at the variety of sexual lifestyles among the lower animals. What if Aquinas had argued from dogs and cats to humans? He might also have taken a better look at human anatomy. As the feminist theologian Christine Gudorf remarks, "If the placement of the clitoris in the female body reflects the divine will, then God wills that sex is not just oriented to procreation, but is at least as, if not more, oriented to pleasure as to procreation" (1994, p. 65) $\square$ for women, anyway. "If anything served ... as an argument for the existence of God, ... it was the thousands upon thousands of orgasms dancing on the head of that pin [,] . . . a gift to each and every little girl from God. All hail the Maker, a generous ... guy with a real soft spot for women” (Roth, 1996, p. 434). So goes a novelist's version of "intelligent design."

Applying Aristotle's virtue of temperance to sex, Aquinas insists that sexual pleasure must be pursued "ordinately," not "inordinately." As in Aristotle, "inordinately" means "in excess" and does not imply "less than is proper." Despite acknowledging God's creation of a natural inclination in humans for sexual intercourse, Aquinas agrees with Augustine on another matter, contrasting the calm sexual relations of prelapsarian Adam and Eve (ST Ia, ques. 98, art. 2) with the "violent" sexuality of animals (which is the word Augustine employs to describe postlapsarian human coitus [COG, bk. 14, chap. 26]). Yet, as if tipping his hat to the Pelagians, Aquinas says that prelapsarian sexual pleasure would have been better, even if not a vital fire: "the pleasure of sense would have been all the greater, given the greater purity of man's nature and sensibility of his body." (This is similar to Wilhelm Reich's view [see below] that sexual relations would be more enjoyable in the paradise of communism.) Aquinas adds, however, that "the pleasure urge would not have squandered itself in so disorderly a fashion on this sort of pleasure when it was ruled by reason" (ST Ia, ques. 98, art. 2, reply 3). What was on Adam and Eve's daily schedule or routine from which they would be distracted by inordinate, squandering sex? Naming the animals? Unlike later theologians who avoided sex by holding study groups on retreats, Adam and Eve had no Talmud or scripture to ponder, nor could they devote themselves to Plato's "assigned regimen of philosophy." And because they had not yet fallen, what was there to accomplish by engaging in Jerome's spiritual procreation? 
The most provocative, even notorious, judgments Aquinas made about human sexuality derive from his Natural Law ethics (ST IIaIIae, ques. 154, arts. 1-12). He distinguishes between two kinds of "sin of lechery." In one kind, "the act of its nature is incompatible with the purpose of the sex-act. In so far as generation is blocked, we have unnatural vice, which is any complete sex-act from which of its nature generation cannot follow." Aquinas provides four examples:

First, outside intercourse when an orgasm is procured for the sake of venereal pleasure; this belongs to the sin of self-abuse. ... Second, by intercourse with a thing of another species, and this is called bestiality. Third, with a person of the same sex ... and this is called sodomy. Fourth, if the natural style of intercourse is not observed, as regards the proper organ[s].

In such acts, procreative organs (and nonprocreative organs, in oral and anal sex) are misused, contrary to their God-given design and purpose, for the goal is sexual pleasure alone, apart from procreation. Notice that Aquinas talks here about "complete" (ejaculatory) sexual acts, thereby focusing on the penis. He does not want the seed wasted by its going elsewhere than into the "proper vessel," the vagina. (Hebrew theology of unnatural sex is similar; see Epstein, 1948, pp. 132-147.) Aquinas assembles these four vices into a hierarchy of sinfulness. "To compare unnatural sins of lechery, the lowest rank is held by solitary sin. . . The greatest is that of bestiality, which does not observe the due species. . . Afterwards comes sodomy, which does not observe due sex. After this is the lechery which does not observe the due mode of intercourse." Masturbation is at the bottom of the list, but it is still unnatural and sinful.

In the second kind of sin of lechery, "the nature of the act with respect to the other party" is sinful. Among Aquinas's examples are heterosexual incest, heterosexual adultery, heterosexual rape, and a man's seduction of a female virgin who lives in her father's house. These acts can be procreative (in form), so they are not unnatural. They are sinful because they violate a justified social morality in which harming others is a moral wrong. To a great extent though, the property rights that men have over women are violated, for Aquinas, in adultery and seduction. This is the kind of philosophy that made rape in marriage legally unthinkable in the West for so long.

Aquinas constructs another hierarchy, between the two types of sin of lechery. "Since ... unnatural vice flouts nature by transgressing its basic principles of sexuality, it is in this matter the gravest of sins." Bestiality, same-sex acts, heterosexual variations, and masturbation are cardinal sins, while incest, adultery, rape, and seduction are only venial. Aquinas replies to an imaginary interlocutor who argues (with a contemporary ring, sounding like Jeremy Bentham and J. S. Mill; see below) that unnatural sex is not the morally worst. "The more a sin is against charity," the interlocutor pleads, "the worse it is. . . [A]dultery and seduction and rape harm our neighbour, whereas unnatural lust injures nobody else, and accordingly is not the worst." But Aquinas tries to refute this reasonable argument, insisting that unnatural sexual vice, including masturbation, is "the gravest of sins" and worse than rape, adultery, and so forth. The unnatural sins of lechery violate the design of God's creation and are an "affront to God." Those people who commit them snub their noses at the Lord and impugn His wisdom, whereas committing rape, seduction, or adultery violates only "the developed plan of living according to reason" that "comes from man." The interlocutor's questions -- If unnatural sexual acts are engaged in by 
consenting adults and harm no one, how could they be wrong? Isn't rape wrong precisely because it is involuntary by force or otherwise lacks consent? -- are still much debated today. (For a comprehensive account of medieval sexual philosophy, see Brundage, 1987.)

\section{Modern Philosophy through the 19th Century}

After the medieval scholastics, from 1550 through the late 1800s, a stream of colorful philosophers wrote about sexuality. Michel Montaigne (1533-1592) was well known for his skeptical epistemological philosophy (we can know nothing) and for his essay "On Friendship," which contains this famous line about his relationship with Étienne de La Boétie: "If you press me to tell why I loved him, I feel that this cannot be expressed, except by answering: Because it was he, because it was I" (Essays, p. 139). In the essay "Of the Power of the Imagination," Montaigne elegantly repeats Augustine's biomedical point: "People are right to notice the unruly liberty of this member, obtruding so importunately when we have no use for it, and failing so importunately when we have the most use for it, and struggling for mastery so imperiously with our will, refusing with so much pride and obstinacy our solicitations, both mental and manual" (Essays, p. 72). We are left to decide the relative impudence of Adam's disobeying God and the penis's disobeying postlapsarian Adam.

Not much later, the French rationalist philosopher René Descartes (1596-1650), whose often misunderstood "cogito, sum" ("I think, I am" — no "therefore") was intended to refute skepticism, including Montaigne's, by displaying some things we can know. Descartes asserted about sexuality that

\footnotetext{
Although we see many persons of the opposite sex, yet we do not desire many at one time. . . But when we observe something in one of them which is more attractive than anything we observe at that moment in others, this determines our soul to feel towards that one alone all the inclination which nature gives it to pursue the good which it represents as the greatest we could possess.

(Philosophical Writings, p. 360)
}

Sexual desire is exclusive (serially) by its nature, for "at that moment" we cannot desire another person. Descartes, unlike Augustine, drew a distinction between sexual desire and the desires to eat and drink, for we rarely think that the desire we have for the steak on the menu could not be satisfied by any plate of steak to come from the kitchen. This feeling that the object of our sexual desire cannot be replaced might be illusory (but see Roger Scruton, below). Note that Descartes says only that nature "represents" this good, that is, embracing the object of our attention, "as the greatest we could possess," suggesting (an idea elaborated by Schopenhauer; see below) that what we think is for our good is not, after all, for our good.

Across the channel, Thomas Hobbes (1588-1678) wrote his 1651 masterpiece, Leviathan. In light of its most famous passage ( $\$ 1.13)$, we could speculate that Hobbes believed that sexual encounters were "nasty, brutish, and short" $\square$ unless you were "poor," in which case they would surely be "solitary." Hobbes wrote little about sexuality, but one provocative exception is this passage from his Human Nature: 
The appetite which men call lust, and the fruition that appertaineth thereunto, is a sensual pleasure, but not only that; there is in it also a delight of the mind: for it consisteth of two appetites together, to please, and to be pleased; and the delight men take in delighting, is not sensual, but a pleasure or joy of the mind consisting in the imagination of the power they have so much to please. (§9.15)

Hobbes, too, denies Augustine's resemblance among the desires for sex, food, and drink, for on his account sexual desire is a compound composed of two distinct desires, a desire to be pleased by the other person and (surprisingly) a coexistent desire to please the other person. The latter desire has no analogue in eating and drinking; as Aristotle says, having good will toward a jug of wine is "ridiculous" and at best vicarious shorthand for anticipating that we will enjoy drinking it (NE 1155b29-30). Hobbes does not develop his thesis, but at least one contemporary philosopher has championed it (Blackburn, 2004, pp. 87-88), making Hobbes a hero for theorizing that sexual desire has this dualistic nature. (Contrast Goldman's [1977] monistic account of sexual desire, as a desire exclusively for one's own sexual pleasure.) Blackburn's praise, however, overlooks the sinister implications of what Hobbes actually says, that a person wants to please the other person because doing so confirms one's sexual powers (a masculine performance principle?), not because it makes the other person happy and not even because it adds to one's sensual pleasure. Hobbes apparently thinks that these motives are characteristic of humanity both in civil society and in the pre-social State of Nature, which yields a different picture of sexuality in Eden: Adam not as Everyman, but as Macho Man.

During the 1700s, David Hume (1711-1776) and Immanuel Kant (1724-1804) weighed in, well before Thurber and White but without their humor, on the issue of the relationship between sexual desire and love. In a chapter of his Treatise of Human Nature entitled "Of the amorous passion, or love betwixt the sexes" (bk. II, pt. ii, chap. 11), Hume claimed that

love, which arises betwixt the sexes ..., is deriv'd from the conjunction of three different impressions or passions[:] The pleasing sensation arising from beauty; the bodily appetite for generation; and a generous kindness or good-will.

About these three "impressions" or "passions" from which love is "derived," Hume asserts that "there arises such a connexion betwixt the sense [perception] of beauty, the bodily appetite, and benevolence, that they become in a manner inseparable." Remarkably, these three features of the amorous passion are, once they come together, "inseparable" $\square$ even though, as Hume readily acknowledges, sexual desire (the "appetite for generation") and benevolence ("generous kindness") are "too remote [by their natures] to unite easily." Why, though, are sexual desire and benevolence too disparate to be joined?

Kant had an answer: "True human love ... admits of no distinction between types of persons, or between young and old. ... Human love is goodwill, affection, promoting the happiness of others and finding joy in their happiness" (Lectures, Ak 27:384). Here Kant is describing the generous kindness component of Hume's amorous passion. This benevolence is so different from sexual desire that they cannot be joined. On Kant's view, passion

that springs ... from sexual impulse cannot be love at all, but only appetite. . . [I]t is clear that, 
when a person [wants] . . . another . . . from sexual desire, none of these factors [the benevolence] enter into [it]. . . Sexual [desire] . . . makes of the [desired] . . . person an Object of appetite. ... [A]s soon as a person becomes an object of appetite for another, all motives of moral relationship cease to function, because as an object of appetite for another a person becomes a thing. (Lectures, Ak 27:384-385)

Indeed, for Kant, it is not merely that sexual desire and benevolence cannot be combined; the latter "deter[s] one from carnal enjoyment" (Metaphysics of Morals, Ak 6:426). Kant, returning to Plato's sharp contrast between vulgar and heavenly eros, is repeating Augustine's Christian thesis about love: "Whoever loves another as himself ought to love that in him which is his real self. Our real selves are not bodies. . . Human nature is to be loved . . . without any condition of carnal relationship" (O'Connell, 1969, p. 111). Again we are confronted by the divide between mind (love) and flesh (sex).

Hume proposed that benevolence and sexual desire could be joined together by the third ingredient of the amorous passion: "beauty is plac' $d$ in a just medium betwixt them, and partakes of both their natures: From whence it proceeds, that "tis so singularly fitted to produce both." This thesis is a curious (or fascinating) piece of Hume's account of the relationships among the three components of the amorous passion. Hume observes that the amorous passion, the mixture of the three, can arise in different ways. A person might feel benevolence toward another person, from which both sexual desire and an appreciation of the other's beauty result. Sensing beauty in another because one has generous kindness toward him or her is not psychologically unusual. (It is similar to God's agape, in which God bestows value on humans in virtue of His loving them.) But to claim that feeling benevolence toward another person is a reliable cause of feeling sexual desire for him or her is implausible. Hume realizes this and admits that rarely does the amorous passion arise in this fashion. Instead, most cases of the amorous passion begin by one person's appreciating another's beauty, which causes both benevolence and sexual desire. (How both, is the puzzle.) Hume, having his feet on solid everyday ground, also sees that the relationship between beauty and sexual desire is sometimes the reverse: when we are already feeling sexual desire (that is, when we are horny), we reach the judgment that the object of our attention is more beautiful than he or she really is. A martini, too, can make us inflate the merits of the object, as Freud might have put it.

Kant was apparently disgusted by sexuality, for he alleged that after we are satisfied by a sexual act we discard our partner like a lemon we have sucked dry (Lectures, Ak 27:384). Maybe this is why he denied, in contrast to contemporary liberal Kantian philosophers (Mappes, 2007), that as long as competent adults give their consent, their sexual activity is morally permissible. Recall that, for Kant, "as an object of [sexual] appetite for another a person becomes a thing (Lectures, Ak 27:385). Using another person as an object, which is inherent to sexual activity, can be overcome, for Kant, only in marriage (Lectures, Ak 27:388; see Herman, 1993; Soble, 2001). If this philosophy of sex weren't grim enough, Kant, despite being an Enlightenment thinker, developed a philosophical view of sexual perversion strikingly similar to Aquinas's medieval account (Lectures, Ak 27:391-392; see Denis, 1999; Soble, 2003). Those who engage in the crimina carnis contra naturam (masturbation, same-sex sexual activity, bestiality) treat themselves as objects and "degrade human nature to a level below that of animal nature and 
make man unworthy of his humanity." Kant, though, has an interesting view of Adam and Eve:

In the case of animals, sexual attraction is merely a matter of transient, mostly periodic impulse.
But man soon discovered that for him this attraction can be prolonged and even increased by
means of the imagination.... By means of the imagination, he discovered, the surfeit was avoided
which goes with the satisfaction of mere animal desire. The fig leaf ... was a far greater
manifestation of reason than that shown in the earlier stage of development. ("Conjectural
Beginning of Human History," 56-57)

Today, Kant's philosophy has been mined by feminists and others who criticize the sexual objectification of women in rape, sexual harassment, prostitution, and pornography (see, for example, Estes, 2008; Nussbaum, 1995). His notion of the wrongfulness in itself of treating a person in sexuality as an object, as a thing to be used, again implies, in contrast to liberal sexual ethics, that the presence of consent is too weak to justify much sexual behavior.

In the first half of the 19th Century, the Danish Christian-existentialist philosopher Søren Kierkegaard, using his playful pseudonyms to good effect, made many provocative observations and counter-observations about sexuality. Some are fun to contemplate (even if obscure), which shows that he could often be as amusing as Thurber and White:

If it is ridiculous to kiss an ugly girl, it also is ridiculous to kiss a pretty one, and the notion that doing a thing one way is any justification for laughing at a person who does it another way is nothing more than superciliousness and a complot. (Stages on Life's Way, p. 54)

Insightfully, he wrote, "When two people fall in love with each other and sense that they are destined for each other, it is a question of having the courage to break it off, for by continuing there is only everything to lose, nothing to gain" ("The Rotation Method of Crops," Either/Or, Vol. 1, p. 298). He followed this with the counterargument (using a different pseudonym) that erotic love and marriage are, after all, compatible ("The Aesthetic Validity of Marriage," E/O, Vol. 2). We also find this contrary repetitive gem: "Marry, and you will regret it. Do not marry, you will also regret it. Marry or do not marry, you will regret it either way. Whether you marry or do not marry, you will regret it either way" ("Diapsalmata," E/O, Vol. 1, p. 138). As Kant did, but more poetically, the mature Kierkegaard emphasized that eros and Christian agape were incompatible: "All pleasure is selfish. The pleasure of the lover . . . is not selfish with respect to the loved one, but in union they are both absolutely selfish, inasmuch as in union and in love they constitute one self" (Stages, p. 56). As a result, "The more securely the two I's come together to become one I," the more in loving each other, they love only themselves (Works of Love, p. 68).

The German philosopher Arthur Schopenhauer (1788-1860), anticipating Darwin's evolutionary biology and Freud's psychoanalysis, painted a bleak picture of the human condition. Plato warned us, in the Symposium, that what we think (consciously) we want in our erotic affairs is not really what we want. Eros, our yearning desire for attractive bodies and excellent minds, is really eros for an Ideal Beauty that is barely represented by the objects of our attachment (211a). We think happiness will result from relationships with beautiful people, but we are dissatisfied. Plato means that we eventually tire of the repetition of earthly beauty and 
that it is fleeting and fragile, whether physical or mental. Dissatisfied with ordinary beauty, we search for an other-worldly Ideal Beauty. An optimist, Plato thought we could succeed in this quest. For Augustine, similarly, the search for the ideal is hidden beneath our erotic loves:

I had not yet fallen in love, but I was in love with the idea of it. . . . I began to look around for some object for my [romantic] love. ... Although my real need was for you, my God, . . . I was not aware of this hunger. (Conf., bk. 3, chap. 1)

Augustine, too, was an optimist. We should seek, however, the personal Christian God, not Ideal Beauty, Plato's inanimate universal.

In Schopenhauer's vision, the beauty of the object of sexual desire is nature's way of tricking a man into thinking that satisfying his erotic desires is for his own individual good. To the contrary, sexual love benefits only the species, for the good of which nature makes use of us, causing us to give up, irrationally, fortune and freedom to attain our erotic goals (recall Plato's "neglect and loss and property"):

\begin{abstract}
Nature can attain her end only by implanting in the individual a certain delusion, and by virtue of this, that which in truth is merely a good thing for the species seems to him to be a good thing for himself. . . . It is a voluptuous delusion which leads a man to believe that he will find a greater pleasure in the arms of a woman whose beauty appeals to him than in those of any other ... [and] firmly convinces him that her possession will afford boundless happiness. Accordingly, he imagines he is making efforts and sacrifices for his own enjoyment, whereas he is doing so merely for the maintenance of ... the species. (The World as Will, pp. 538, 540)
\end{abstract}

Note the twist that Schopenhauer puts on the Christian view of marital parenthood as being our contribution to God's ongoing creative project. For Schopenhauer, evolution resorts to deceptive beauty to enlist the aid of otherwise reluctant humans in nature's creative scheme. Why do we have to be tricked into having sex? Sex is burdensome: pursuing a mate uses resources and the act produces children we then have to care for. Further, the "sense of beauty ... directs the sexual impulse, and [is that] without which this impulse sinks to the level of a disgusting need" (World, p. 539). As in Kant and Augustine, sexuality is disgusting, so we must be cajoled into it.

Also in the early 19th Century, Jeremy Bentham (1748-1832), relying on his utilitarian ethics (which tells us to aim always for the "greatest good of the greatest number"), defended consensual same-sex sexual activity, on the grounds that it produced pleasure and had no damaging or dangerous social effects. Bentham's “An Essay on 'Paederasty'," however, was not published during his lifetime; indeed, it did not appear in print until 1978. The essay, then, could not have been of any benefit to persecuted homosexuals in 19th-century England. Later in the century, Bentham's student, John Stuart Mill (1806-1873), writing in an unreceptive Victorian climate, announced at the beginning of his Subjection of Women that "the principle which regulates the existing social relations between the two sexes -- the legal subordination of one sex to the other -- is wrong ... [and] ought to be replaced by a principle of perfect equality." Mill's feminist credentials are not in doubt. But he wrote little about sex, unlike contemporary feminists, for whom it is frequently the main issue (for example, MacKinnon [1987] on rape, pornography, and prostitution). 
In On Liberty, Mill relies on several sexual examples to illustrate the application of his utilitarian moral theory. He finds Mormon polygyny disagreeable, yet argues that the consent of the women to the arrangement is what counts (OL, chap. 4). Feminists wish that Mill had probed deeper into the authenticity of their consent. Mill contends that "fornication" must be tolerated, when it is consensual and harms no one, and that houses of prostitution should not be prohibited but only regulated: "they may be compelled to conduct their operations with a certain degree of secrecy and mystery, so that nobody knows anything about them but those who seek them" (OL, chap. 5). Don't ask, don't tell. Mill praises and defends extensive social and legal liberty that would allow and even encourage "experiments in living" (OL, chap. 3), but he did not draw out the obvious implication about the value of a plurality of sexual lifestyles. Mill's formulation of utilitarianism remains popular today, among philosophers, along with the ethics of Kant's Categorical Imperative and Aristotelian virtue theory. These three dominate the secular scene in normative philosophy of sex, while Augustine and Aquinas are still strongly influential in theological circles.

As was Mill, Karl Marx (1818-1883) and Friedrich Engels (1820-1893) were centrally concerned with economic and political questions. Contemporary feminism owes to Marx and Engels the idea that prostitution and marriage are not very different. A married woman "differs from the ordinary courtesan [only] in that she does not let out her body on piece-work as a wage earner, but sells it once and for all into slavery" (Engels, Origin of the Family, Private Property, and the State, p. 82; see also Emma Goldman's 1917 “The Traffic in Women”). In their jointly written Communist Manifesto (p. 72), Marx and Engels assert that communism (the abolition of private ownership of the means of production) would release women from "prostitution, both public and private," from both streetwalking and loveless marriages contracted out of economic necessity. What was wrong with prostitution provided Marx with insight into the defects of capitalism: "Prostitution is only a particular expression of the universal prostitution of the worker." His further point is that

\footnotetext{
Money, inasmuch as it possesses the property of being able to buy everything . . is the object most worth possessing. . . . I am ugly, but I can buy the most beautiful woman. Which means .. . that I am not ugly, for the effect of ugliness, its repelling power, is destroyed by money.
}

In the transaction by which the bourgeois male acquires his trophy wife, "Money is the pimp between need and object" (Economic and Philosophic Manuscripts, pp. 133, 165). Marx and Engels's dislike of philosophy and their Victorian attitude toward sexuality are revealed in this morsel: "Philosophy and the study of the actual world have the same relation to one another as masturbation and sexual love" (German Ideology, p. 103). Disparaging metaphors are often used to describe philosophy ("head in the clouds navel-picking") but comparing it with masturbation is double-edged. As Surgeon General Joycelyn Elders announced in 1994, thereby precipitating her removal from the Clinton administration, masturbation is safe sex and avoids pregnancy (Elders, 1997; Soble, 2006). And while you are reading this philosophical essay, you're keeping out of trouble. 


\section{The Early 20th Century}

Amidst the psychoanalytic twist in psychology, the linguistic turn in philosophy, and the advance of evolutionary theory, came an outpouring of sometimes shocking inquiries into sex.

It began with Sigmund Freud's (1856-1939) Three Essays on the Theory of Sexuality (1905), which challenged dominant beliefs about children's sexual innocence and the innateness of heterosexuality. His theoretical advance was distinguishing among the sexual instinct (libido), the aim of the sexual instinct, and the instinct's object. An instinct's aim is the state or condition it seeks, while its objects are the items in the world it uses to attain that state. The food instinct aims to appease an unpleasant feeling, hunger, and to get nutrition; its objects are edible portions of the world. Sex, too, involves an instinct, but it is different. (Freud, to a small extent, broke away from the Augustinian conflation of sex, eating, and drinking.) The objects of the food instinct are determined by the instinct. Only certain parts of the world -- a genuine hamburger, not a menu's picture of a hamburger, nor a fantasized hamburger -- satisfy the drive. The instinct, the aim, and the object are locked. Not so for sexuality. There is no analogue in hunger and eating to getting pleasure by masturbating with sexual fantasy; it is masturbation (childhood autoerotism, especially) that blows apart the theoretical lock among instinct, aim, and object. In sexuality, says Freud, the sexual instinct and its objects are "merely [that is, artificially] soldered together" (Three Essays, p. 148). The aim is sensual, bodily, pleasure, and its objects are nearly limitless. The hungry, crying child, when given milk, survives; given other fluids (engine oil), it dies. But a child wanting sensory pleasure can be touched or rubbed by many things to achieve somatic pleasure: males, females, rugs, animals, its own thumb. Hence children, as Freud says, are polymorphously perverse. Which of the objects in the world that are eventually preferred for pleasure by a person is determined by his or her psychobiography. Hence, for Freud, "Why are there homosexuals?" is the wrong question. The task, that is, is explain not only homosexuality but also heterosexuality. As soon as the sexual instinct and its objects are kept distinct, no basis exists for a Thomistic anatomical or physiological criterion of unnatural sex. Homosexuality is off that hook; it is not unnatural merely because it is not reproductive. The criteria of perversion must be, instead, psychological, and hence more complex (Neu, 1991). The American Psychiatric Association admitted this in the mid-1970s, when it excluded homosexuality per se from DSM (Soble, 2004).

The British philosopher Bertrand Russell (1872-1970) also caused a stir. His Marriage and Morals (1929) mixed a prescient and formidable feminism (he was an outspoken activist for the equality of women) with a utilitarian criticism of marital sexual fidelity $\square$ a defense of what we now call "open marriage." Marriage and Morals was, for some, a lecherous book, and cost Russell an appointment at the City University of New York. Yet "so much of what [Russell] ... called for ... has been achieved by the sexual revolution and the feminist movement that I suppose no one reads [Marriage and Morals] ... any more" (Nagel, 2002, p. 65). On Russell's view, "sexual relations should be a mutual delight, entered into solely from the spontaneous impulse of both parties." This seems tame, although Russell employed the principle to justify honest adultery. His main purpose was to condemn a common motive for sex different from mutual delight and spontaneous impulse: "the intrusion of the economic motive into sex is ... 
disastrous." Russell opposed not only blatant commercial prostitution but also the more subtle conjugal sex that took place only because wives were economically dependent on husbands. Russell, maybe hyperbolically but consistent with some feminism (Morgan, 1977, pp. 163-169), asserted that "the total amount of undesired sex endured by women is probably greater in marriage than in prostitution." This shows how marxist Russell was, or how liberal Marx and Engels were.

Then, during the thick of World War II, Jean-Paul Sartre (1905-1980) wrote Being and Nothingness. Buried in this thick metaphysical treatise is a section on sexuality, as a central case of human attitudes. Sartre proclaimed that the battle of the sexes was the tip of an iceberg that would have frozen even the hard-nosed Hobbes:

\footnotetext{
Sadism and masochism are the two reefs on which desire may founder $\square$ whether I surpass my troubled disturbance toward an appropriation of the Other's flesh or, intoxicated with my own trouble, pay attention only to my flesh and ask nothing of the Other except that he should be the look which aids me in realizing my flesh. It is because of this inconstancy on the part of desire and its perpetual oscillation between these two perils that "normal" sexuality is commonly designated as "sadistic-masochistic." (BN, pt. 3, chap. 3, sect. 2)
}

Reaching back to G.W.F. Hegel's (1770-1831) account of the "master-slave" relationship (Phenomenology of Spirit, $\S \S 178-196)$, Sartre theorized that in sexual interactions one person always desires to capture the freedom of another. That endeavor is doomed to fail or to shoot itself in the foot. For if we capture the other's freedom, we see that our victory is nugatory; we have nothing significant left to dominate or control. Soon after Being and Nothingness came The Second Sex by Simone de Beauvoir (1908-1986), Sartre's companion and lover, which expressed primordial yet fertile feminist accounts of sex and gender: "One is not born, but rather becomes, a woman" (p. 267), she famously wrote, emphasizing that culture played a more important role in the formation of gender than biology. Beauvoir's essay "Must We Burn Sade?" helped garner for the Divine Marquis a scholarly appreciation, at least among French scholars. Of some interest to historians is that Sartre and Beauvoir's relationship was like the open, honest infidelity advocated by Russell. Depending on which biographer is consulted, this bold (Millian) experiment in living was either a mediocre success or a miserable failure, causing much anguish to Simone. Still, they share a tomb in Paris.

Coming before and after the existentialists Sartre and Beauvoir were a number of radical social and political philosophers, including Wilhelm Reich (1897-1957), Herbert Marcuse (18981979), and members of the Frankfurt School. Reich and Marcuse thought that Marxism, which lacked a psychological "branch," was as a result theoretically insufficient for understanding economic and political history. Hence they blended Freudian psychoanalysis with Marxism to liberate human sexuality from oppressive Victorian morality and capitalist political tyranny. Freud had argued in Civilization and Its Discontents (1930) that human sexuality must be curtailed, at the expense of the happiness of individuals, for the sake of the greater goods of civilized life. (In this regard, Freud's view is close to Hobbes's argument in Leviathan.) Freud thought that this exchange was overall a fine deal, but also that contemporary (for him) social arrangements required too much curtailment of sexuality, that the leash could be loosened so that 
people would be better off sexually without harming civilization. Marcuse, who grabbed himself a place in the history of pop culture by advising young people to "make love, not war," continued Freud's project in his 1955 Eros and Civilization. Marcuse coined the term "surplus repression" for the excess and hence unnecessary restriction of sexuality required by oppressive economic and political regimes, arguing that the leash could be loosened more than Freud had thought. Marcuse also coined the term "repressive desublimation" to describe how Western consumer capitalism could loosen the sexual leash and manipulate the resulting pseudo-sexual freedom for its own advantage.

Reich also argued that economic and political changes had to made for the sake of freedom, so that people would have more satisfying sex lives. He got himself into trouble for setting up birth control clinics in Berlin in the early 1930s. Reich was not only a political activist but also a theoretician, an epistemologist of human nature. He developed the idea (which was hinted at by Freud in Future of an Illusion) that if we want to discover the genuine nature of human sexuality, we can do so only when people are free from social influences and can thereby explore sexually whatever they feel like (see Sex-Pol and Sexual Revolution; Soble, 1986, pp. 10-37). In this way, the Garden of Eden and Hobbes's State of Nature make their way into radical sexual politics. The irony is that Reich thought that pure human sexuality would be heterosexual, and that the sexually unnatural acts that Aquinas, Kant, and others condemned were symptoms of the influence of economic and social corruption on human behavior. (Strains of Jean-Jacques Rousseau's [1712-1778] Discourse on Inequality can be discerned here.) Reich offered a psychological and political approach to the problems of sexual relations, as opposed to the theological approach of Augustine and Aquinas, but in effect arrived at a similar picture of the perfectly healthy sexuality of the communist comrades Adam and Eve.

\section{Contemporary Philosophy}

Many professional philosophers wrote about human sexuality in the last quarter of the 20th Century and beyond, so many that describing what each or even a large set have contributed to the field would be unwieldy. Several figures stand out, however, as being the most significant, by peer reviews of their writings and how often their work is cited. A few words about them is in order.

In 1969, Thomas Nagel anglicized Hegel and Sartre, fashioning from them, in "Sexual Perversion," a non-Thomistic and non-Freudian theory of psychologically perverted sexuality. It is routinely acknowledged that Nagel's essay inaugurated contemporary philosophy of sex, for it was immediately followed by a swarm of sophisticated elaborations and rebuttals (Nelson, 2006). Though there is no consensus that Nagel was successful in his novel way of understanding sexual perversion, he stimulated the philosophical investigation of sexuality in fruitful directions. On Nagel's view of human sexuality, self-consciousness plays a role that is missing from animal sexuality. At the beginning of a sexual episode, I am aroused by sensing (touching, looking at, smelling) you. You, too, are aroused by sensing me at this basic (merely animal) level. While I am aroused by sensing you, I perceive myself as a sexual subject. As our interaction proceeds, I respond with increased arousal to noticing that you are aroused by sensing 
me. Now I perceive myself as the object of your sexual consciousness; I become aware of myself through your gaze. If the same holds for you, we both perceive ourselves at once as both subject and object in the sexual episode, which phenomenon makes human sexuality distinct from and more interesting than animal sexuality. This configuration is characteristic of natural human sexuality, according to Nagel, so that perversion is a preference for sexual acts that avoid this reciprocal recognition of sexual arousal (Soble, 2008, Table 1). Voyeurism is a good example of a Nagelian perversion. The voyeur prefers to remain a sexual subject, keeping himself hidden from the look of others, never experiencing the self-conscious embodiment of a sexual object. (Aquinas agrees that voyeurism is unnatural, but for a different, biological reason. They disagree about homosexuality, which is psychologically natural on Nagel's scheme.) An illuminating feature of Nagel's account is how it captures what happens when a prostitute feigns enjoying the sex for which she is paid (or when a spouse pretends, for the sake of the pleasure of the other spouse, to enjoy their boring sexual activity). To be rid of the client and save time, the prostitute helps him reach orgasm quickly. She feigns arousal, knowing that when this "arousal" is perceived by the client, this will increase his arousal in a Nagelian spiral. The client becomes conscious of himself as both subject and object; finding this state blissfully pleasurable, he loses no time achieving orgasm.

In his erudite and philosophically elegant Sexual Desire (1986), politically conservative British philosopher Roger Scruton rehabilitated everything traditional, from sexual fidelity in marriage to Aquinas's and Kant's condemnation of masturbation, and in a social climate already highly sensitive to issues surrounding sexual orientation, Scruton was not afraid to doubt and criticize the normality, morality, and social effects of homosexuality. Scruton, using his notion of "individualising intentionality" (1986, pp. 103-107), strongly distinguished, against Kant and Augustine, sexual desire and the desires for food and drink: the object of human sexual desire, in contrast to animal desire, is an irreplaceable individual (contrast Soble, 1990, pp. 293-298). He thus drew a line between focused human sexual desire and wide-ranging animal horniness, which humans also experience, but act on only at their peril. As part of his traditionalism, Scruton rehearsed a standard way of contrasting sex and love:

Love has a tendency to grow with time, while desire has a tendency to wither. The course of love, therefore, leads of its own accord to the state which the Platonists [and Christians] recommend to us. Eventually desire is replaced by a love which is no longer erotic, but based in trust and companionship. The trouble of desire is then at an end. (1986, p. 244)

Scruton, with candor, immediately points out that "The problem [now] is, how to shut out the third party, who will begin it again, how to prevent the calm love of nuptial union from being shattered by the turbulence of a new desire. Not only how, but whether." To cheat or not to cheat, that is the question. Or why "shut out" the third instead of inviting him or her in?

Traditional sexual philosophy is also defended by Karol Wojtyla (1920-2005; Pope John Paul II) in an ambitious project that combines the "personalist norm" of Kantian ethics (do not use people or treat them as objects) and the Christian love commandment. Written while he was still a philosophy professor in Poland, well before Wojtyla became pope, his book Love and Responsibility tackles in an intellectually honest way puzzles that plague Catholic sexual ethics. 
For example, he seriously investigates why, in Catholicism, contraception is prohibited but natural family planning, or "periodic continence," is licit (pp. 237-244). Wojtyla makes it clear (as Kierkegaard did) that in Christian marriage, eros takes a back seat to agape:

\footnotetext{
The most important concept here is that of love. . . For there exists, especially if we start from the Christian ethics born of the New Testament, a problem which can be described as that of "introducing love into love." The word as first used in that phrase signifies the love which is the subject of the greatest commandment, while in its second use it means all that takes place between a man and a woman on the basis of the sexual urge. We could look at it the other way round and say that there exists a problem of changing the second type of love (sexual love) into the first, the love of which the New Testament speaks. (Love and Responsibility, p. 17)
}

This is Wojtyla's way of saying that in marriage "desire is replaced by a love which is no longer erotic" (Scruton) and that a man must not turn his wife into his harlot (Augustine). Some find in the sometimes outrageous, and hardly Orthodox, writings of Rabbi Shmuley Boteach (Kosher Sex, 1999; Kosher Adultery, 2002) the antidote to this conservative and Christian condemnation of hot married sex. The Rabbi out-pelagians the Pelagians by suggesting techniques that married couples can use to keep the vital fire alive in their sexual relationship.

Several legal scholars have made important contributions to the philosophy of sex. In Sex and Reason (1992), law professor and U.S. circuit court judge Richard Posner expounded a nononsense, pragmatic, utilitarian ethical and legal philosophy of sex, articulating what we should expect from homo economicus (for example, a man can be expected to rape a woman if that is the least expensive or only way of injecting his genes into the next generation). Law professor and political philosopher, Catharine MacKinnon, after her early influential and innovative work on sexual harassment (1979), dramatically escalated the battle of the sexes in Only Words and Feminism Unmodified. She seemingly declared that in patriarchy (e.g., the contemporary U.S.) all heterosexual intercourse is rape, because women, universally and deeply oppressed, are unable to give genuine consent to sexual activity with men, who are economically, socially, politically, and psychologically more powerful (compare MacKinnon, 1997, with Estlund, 1997, Soble, 1996, pp. 244-247). Judge Posner, among others, especially male scholars who legally defended pornography, came under attack (MacKinnon, 1997). Some commentators have sympathetically perceived affinities among MacKinnon's gruesome depiction of heterosex, the often frightening descriptions of contemporary heterosexuality penned by her colleague Andrea Dworkin (1987), and the sexual metaphysics of Kant (Herman, 1993; Nussbaum, 1995). Comparisons like these fuel the interpretation of current radical feminism (as opposed to liberal feminism) that this form of feminism is conservative sex-negativity disguised by fashionable emancipatory jargon (Soble, 2002, pp. 195-197).

A third lawyer and philosopher, John Finnis, joined by theologian Germain Grisez (1988) and other New Natural scholars, undertook to modernize Thomas's sexual philosophy. Denying that same-sex sexuality and same-sex marriage are morally permissible, Finnis (1994) defended the controversial Catholic distinction between the morally permissible sexual intercourse of a contingently, medically infertile heterosexual couple and the morally illicit sexual activity of a necessarily sterile gay or lesbian couple (Koppelman, 2008; Nussbaum, 1994). This distinction 
has connections with another contentious Catholic distinction, between morally impermissible heterosexual coitus in which procreation is deliberately impeded by contraception and morally permissible heterosexual coitus that is not procreative because the couple has confined the act to the (probably) infertile stage in the wife's cycle (see Noonan, 1986, appendix).

Of special significance is the French "renaissance" scholar Michel Foucault (1926-1984), who caused a thunderstorm among philosophers, historians, and other theorists of sex with his Histoire de la sexualité (1976-1984). Foucault sparked "genealogical" studies informed by the heuristic idea that not only are patterns of sexual desire and behavior socially engineered, as foreseen by Beauvoir and promulgated by Adrienne Rich (1986), but also that the concepts of our sexual discourse are equally socially constructed: "Sexuality must not be thought of as a kind of natural given which power tries to hold in check. . . It is the name that can be given to a historical construct" (History, Vol. 1, p. 105). Foucault was in part reacting against the type of discourse about natural sexuality, found in Freud, Reich, and Marcuse, as that which would be uncovered as layers upon layers of socialization were gradually peeled away. Foucault greatly influenced gender studies, feminism, Queer Theory, and the debate about the resemblance and continuity, or lack of it, between ancient and contemporary homoeroticism (Davidson, 2002; Halperin, 1990). One issue is whether homosexuality as an orientation began existing when the Magyar sexologist Károly Mária Benkert (1824-1882) coined the word "homosexual" in 1869, a word unknown among the ancients, who could well have invented it had they deemed doing so to be medically, socially, or even philosophically meaningful. Medical sexology in late 19thcentury Europe did detect value in picking out a class of persons as "homosexual" $\square$ as particular objects for therapy. This focus on sexual orientation and sexual identity continues today, not necessarily for psychiatric reasons, but also for the political advantage of the LGBT community.

Where does the philosophy of sex stand today? The earliest contemporary philosophers of sex, who contributed to the rise of the field in the 1970s through the 1990s, are getting older and nearing retirement or retired. Younger scholars have moved into the field, carrying, perhaps, less obnoxious 1950s baggage with them as they explore in their own way their own distinctive set of sexual topics in the 21st Century. As philosopher of science Thomas Kuhn famously observed, progress (or at least change) in a discipline comes about as much by attrition and replacement as it does by new and better discoveries. I might venture the opinion that the older contemporaries repeated in great measure, albeit with their own idiosyncratic styles and twists, philosophies that had been around during the whole course of the history of the philosophy of sex, from Plato through Russell. Whether younger philosophers of sex -- not by forgetting history, but by transcending it -- will be able to fashion more illuminating discourses is unclear. Marx might bemoan yet another case of the effect of the weight of history on human thought and practice. Philosophy can defend itself only by reminding us that it is unique in being a discipline in which no advances are made except the continuation of the discussion, where that prolonged discussion is the whole, and valuable, point of the activity. ${ }^{2}$ 


\section{Notes}

1. Leading textbooks and reference works include Baker et al., eds., 1998; Divine and WolfDevine, eds., 2003; Feder et al., eds., 2004; Gruen and Panichas, eds., 1997; Kuefler, ed., 2007; Nye, ed., 1999; Primoratz, ed., 1997; Soble, 2008, Soble, ed., 1989, 1997; Soble and Powers, eds., 2008; Solomon and Higgins, eds., 1991; Stewart, ed., 1995; Trevas et al., eds., 1997; Tuana and Shrage, 2003; Verene, ed., 1995. Especially useful is Soble, ed., 2006, which contains entries on the topics and figures mentioned in this review. In 1977, a professional organization was formed to support this field, The Society for the Philosophy of Sex and Love. Its web site is at www.philosophyofsexandlove.org.

2. This review is partly derived from lectures delivered at the University of West Florida (2003), Agnes Scott College (2003), Amherst College (2006), Cape Breton University (2006), and Wichita State University (2007).

\section{References}

American Psychiatric Association (1987). Diagnostic and statistical manual of mental disorders (3rd ed., rev.) [DSM-III-R]. Washington, DC: Author.

American Psychiatric Association (1994). Diagnostic and statistical manual of mental disorders (4th ed.) $[D S M-I V]$. Washington, DC: Author.

Appiah, K. A. (1997). Review of Alan Soble, Sexual investigations. Times Literary Supplement (20 June 1997), 5.

Aquinas, T. (1258-64/1956). On the truth of the Catholic faith: Summa contra gentiles, bk. III, pt. 2. Trans. V. Bourke. Garden City, NY: Image Books.

Aquinas, T. (1265-1273/1964-1976). Summa theologiae, vols. 1-60. Cambridge: Blackfriars. Aristotle (ca. 325 BCE/1985). Nicomachean ethics. Trans. T. Irwin. Indianapolis, IN: Hackett. Augustine (397/1961). Confessions. New York: Penguin.

Augustine (418/1993). City of God. New York: Modern Library.

Augustine (418-421/1874). On marriage and concupiscence. In The works of Aurelius Augustine, Bishop of Hippo, Vol. 12 (pp. 93-202). Edinburgh: T. \& T. Clark.

Baker, R. B., Wininger, K. J., \& Elliston, F. A. (Eds.) (1998). Philosophy and sex (3rd ed.). Amherst, NY: Prometheus.

Beauvoir, S. de (1949/1961). The second sex. New York: Bantam.

Beauvoir, S. de (1955/1966). Must we burn Sade? In A. Wainhouse \& R. Seaver (Eds.), The Marquis de Sade: The 120 days of Sodom and other writings (pp. 3-64). New York: Grove Press.

Bentham, J. (1814-1816/1998). An essay on 'paederasty'. In R. Baker, K. Wininger, \& F. Elliston (Eds.), Philosophy and sex (3rd ed., pp. 350-364). Amherst, NY: Prometheus. Blackburn, S. (2004). Lust. New York: Oxford University Press.

Boteach, S. (1999). Kosher sex: a recipe for passion and intimacy. New York: Doubleday. Boteach, S. (2002). Kosher adultery: seduce and sin with your spouse. Avon, MA: Adams 
Media.

Brundage, J. A. (1987). Law, sex, and Christian society in medieval Europe. Chicago: University of Chicago Press.

Carman, B. (Trans.) (1904). Sappho: One hundred lyrics. Boston: L. C. Page. Retrieved December 2, 2007, from Bulfinch's Mythology web site, bulfinch.englishatheist.org/b/Sappho100Lyrics.html.

Clark, E. (1986). 'Adam's only companion': Augustine and the early Christian debate on marriage. Recherches Augustiniennes, 21, 139-162.

Clark, E. (Ed.) (1996). St. Augustine on marriage and sexuality. Washington, DC: Catholic University of America.

Davidson, A. (2002). The emergence of sexuality: Historical epistemology and the formation of concepts. Cambridge, MA: Harvard University Press.

Denis, L. (1999). Kant on the wrongness of 'unnatural' sex. History of Philosophy Quarterly, 16, 225-248.

Descartes, R. (1985). The philosophical writings of Descartes, Vol. 1. Cambridge: Cambridge University Press.

Devine, P., \& Wolf-Divine, C. (Eds.) (2003). Sex and gender. Belmont, CA: Wadsworth.

Dworkin, A. (1987). Intercourse. New York: Free Press.

Elders, M. J. (1997). The dreaded "M" word. Nerve (June 26, 1997). Retrieved April 15, 2008, from the Nerve web site, www.nerve.com/dispatches/elders/mword.

Engels, F. (1884/1942). The origin of the family, private property, and the state. New York: International Publishers.

Epstein, L. M. (1948). Sex laws and customs in Judaism. New York: Ktav.

Estes, Y. (2008). Prostitution: A subjective position. In A. Soble \& N. Power (Eds.), Philosophy of sex (5th ed., pp. 353-365). Lanham, MD: Rowman and Littlefield.

Estlund, D. (1997). MacKinnon. In D. Estlund \& M. Nussbaum (Eds.), Sex, preference, and family (pp. 164-168). New York: Oxford University Press.

Feder, E. K., MacKendrick, K., \& Cook, S. S. (Eds.) (2004). A passion for wisdom: Readings in western philosophy on love and desire. Upper Saddle River, NJ: Prentice Hall.

Finnis, J. M. (1994). Law, morality, and 'sexual orientation.' Notre Dame Law Review, 69, 10491076.

Foucault, M. (1976). The history of sexuality, Vol. 1. An introduction. New York: Vintage.

Foucault, M. (1984/1985). The history of sexuality, Vol. 2. The use of pleasure. New York: Pantheon.

Foucault, M. (1984/1986). The history of sexuality, Vol. 3. The care of the self. New York: Vintage.

Freud, S. (1905/1953-1974). Three essays on the theory of sexuality. In J. Strachey (Ed.), The standard edition of the complete psychological works of Sigmund Freud, Vol. 7 (pp. 125245). London: Hogarth Press.

Freud, S. (1927/1953-1974). The future of an illusion. In J. Strachey (Ed.), The standard edition of the complete psychological works of Sigmund Freud, Vol. 21 (pp. 1-56). London: Hogarth Press.

Freud, S. (1930/1953-1974). Civilization and its discontents. In J. Strachey (Ed.), The standard edition of the complete psychological works of Sigmund Freud, Vol. 21 (pp. 64-145). 
London: Hogarth Press.

Geach, P. (1977). The virtues: The Stanton lectures 1973-74. Cambridge: Cambridge University Press.

Goldman, A. (1977). Plain sex. Philosophy and Public Affairs, 6, 267-287.

Goldman, E. (1917/1969). The traffic in women. In Anarchism and other essays (pp. 177-194). New York: Dover.

Gould, C. S. (2006). Plato. In A. Soble (Ed.), Sex from Plato to Paglia: A philosophical encyclopedia (pp. 800-811). Westport, CT: Greenwood.

Grisez, G., Boyle, J., Finnis, J., May, W. E., \& Ford, J. C. (1988). The teaching of "Humanae vitae": A defense. San Francisco: Ignatius Press.

Gruen, L., \& Panichas, G. F. (Eds.) (1997). Sex, morality, and the law. New York: Routledge.

Gudorf, C. E. (1994). Body, sex, and pleasure: Reconstructing Christian sexual ethics. Cleveland, OH: Pilgrim Press.

Halperin, D. M. (1990). One Hundred Years of Homosexuality. New York: Routledge.

Halwani, R. (2007). Sexual temperance and intemperance. In R. Halwani (Ed.), Sex and ethics (pp. 122-133). New York: Palgrave/Macmillan.

Hegel, G.W.F. (1807/1977). Phenomenology of spirit. Trans. A. V. Miller. Oxford: Clarendon Press.

Herman, B. (1993). Could it be worth thinking about Kant on sex and marriage? In L. Antony and C. Witt (Eds.), A mind of one's own (pp. 49-67). Boulder, CO: Westview.

Hobbes, T. (1640/1966). Human nature, or the fundamental elements of policy. In The English works of Thomas Hobbes, Vol. 4 (pp. 1-76). Aalen, Ger.: Scientia Verlag.

Hobbes, T. (1651/1997). Leviathan, or the matter, forme and power of a commonwealth ecclesiastical and civil. New York: Touchstone.

Homer. (ca. 800 BCE). Iliad. Retrieved January 29, 2008, from The Internet Classics web site, classics.mit.edu/Homer/iliad.html.

Hume, D. (1739-1740/2000). A treatise of human nature. Oxford: Oxford University Press.

Kant, I. (ca. 1762-1794/1997). Lectures on ethics. Trans. P. Heath. Cambridge: Cambridge University Press.

Kant, I. (1786/1963). Conjectural beginning of human history. In L. W. Beck (Ed.), On History (pp. 53-68). Indianapolis, IN: Bobbs-Merrill.

Kant, I. (1797/1996). The metaphysics of morals. Trans. M. Gregor. Cambridge: Cambridge University Press.

Kierkegaard, S. (1843/1983). Fear and trembling and Repetition. Trans. H. Hong \& E. Hong. Princeton, NJ: Princeton University Press.

Kierkegaard, S. (1843/1987). Either/Or, vols. 1 \& 2. Trans. H. Hong \& E. Hong. Princeton, NJ: Princeton University Press.

Kierkegaard, S. (1845/1945). Stages on life's way. Trans. W. Lowrie. Princeton, NJ: Princeton University Press.

Kierkegaard, S. (1847/1962). Works of love. Trans. H. Hong \& E. Hong. New York: Harper and Row.

Koppelman, A. (2008). Homosexuality and infertility. In A. Soble \& N. Power (Eds.), Philosophy of sex (5th ed., pp. 141-154). Lanham, MD: Rowman and Littlefield.

Kuefler, M. (Ed.) (2007). The history of sexuality sourcebook. Peterborough, Can.: Broadview. 
Leo XIII, Pope (1879). Aeterni patris. Retrieved January 29, 2008, from The Holy See (Vatican) web site, www.vatican.va/holy_father/leo_xiii/encyclicals/documents/hf_1xiii_enc_04081879_aeterni-patris_en.html.

Lesser, A. H. (1980). Love and lust. Journal of Value Inquiry 14 (1), 51-54.

MacKinnon, C. A. (1979). Sexual harassment of working women. New Haven, CT: Yale University Press.

MacKinnon, C. A. (1987). Feminism unmodified. Cambridge, MA: Harvard University Press.

MacKinnon, C. A. (1993). Only words. Cambridge, MA: Harvard University Press.

MacKinnon, C. A. (1997). Pornography left and right. In D. Estlund \& M. Nussbaum (Eds.), Sex, preference, and family (pp. 102-125). New York: Oxford University Press.

Mann, T. (1912/1930). Death in Venice. New York: Knopf.

Mappes, T. A. (2007). Sexual morality and the concept of using another person. In T. Mappes and J. Zembaty (Eds.), Social ethics: Morality and social policy (7th ed., pp. 168-183). New York: McGraw-Hill.

Marcuse, H. (1955/1966). Eros and civilization. Boston: Beacon.

Marx, K. (1844/1964). Economic and philosophic manuscripts of 1844. New York: International Publishers.

Marx, K., \& Engels, F. (1845-1846/1970). The German ideology. New York: International Publishers.

Marx, K., \& Engels, F. (1848/1998). The communist manifesto. New York: Penguin Putnam.

Mill, J. S. (1859/1978). On liberty. Indianapolis, IN: Hackett.

Mill, J. S. (1869/1970). The subjection of women. Cambridge, MA: MIT Press, 1970.

Miller, A. (1973). The creation of the world and other business: A play. New York: Viking.

Milton, J. (1667/2000). Paradise lost. London: Penguin, 2000.

Montaigne, M. de (1580-1595/1958). The complete essays of Montaigne. Trans. D. M. Frame. Stanford, CA: Stanford University Press.

Morgan, R. (1977). Going too far. New York: Random House.

Murdoch, I. (1974). The black prince. New York: Warner Books.

Nagel, T. (1969/1979). Sexual perversion. Journal of Philosophy, 66 (1), 5-17; rev. in Mortal questions (pp. 39-52). Cambridge: Cambridge University Press.

Nagel, T. (2002). Concealment and exposure and other essays. Oxford: Oxford University Press.

Nelson, J. L. (2006). Nagel, Thomas. In A. Soble (Ed.), Sex from Plato to Paglia: A philosophical encyclopedia (pp. 678-702). Westport, CT: Greenwood.

Neu, J. (1991). Freud and perversion. In J. Neu (Ed.), The Cambridge companion to Freud (pp. 175-208). Cambridge: Cambridge University Press.

Noonan, J. T., Jr. (1965/1986). Contraception: A history of its treatment by the Catholic theologians and canonists (enlarged ed.). Cambridge, MA: Harvard University Press.

Nussbaum, M. C. (1994). Platonic love and Colorado law: The relevance of ancient Greek norms to modern sexual controversies. Virginia Law Review, 80, 1515-1651.

Nussbaum, M. C. (1995/1999). Objectification. In Sex and social justice (pp. 213-239). New York: Oxford University Press.

Nye, R. (Ed.) (1999). Sexuality. Oxford: Oxford University Press.

O'Connell, R. J. (1969). St. Augustine's Confessions: The odyssey of soul. Cambridge, MA: Harvard University Press. 
Pagels, E. (1988). Adam, Eve, and the serpent. New York: Vintage.

Paul VI, Pope (1968). Humanae vitae. Catholic Mind, 66 (September), 35-48.

Plato (ca. 380 BCE/1970). Symposium. Trans. S. Groden. Amherst: University of Massachusetts Press, 1970.

Plato (ca. 375-370 BCE/1992). Republic. Trans. G. M. Grube. Indianapolis, IN: Hackett.

Plato (ca. 365 BCE/1995). Phaedrus. Trans. A. Nehamas \& P. Woodruff. Indianapolis, IN: Hackett.

Posner, R. A. (1992). Sex and reason. Cambridge, MA: Harvard University Press.

Price, A. W. (1989/1997). Love and friendship in Plato and Aristotle (rev. ed.). Oxford: Clarendon Press.

Primoratz, I. (Ed.) (1997). Human sexuality. Aldershot, UK: Ashgate.

Ranke-Heinemann, U. (1990). Eunuchs for the kingdom of heaven: Women, sexuality and the Catholic church. New York: Penguin.

Reich, W. (1929-1934/1972). Sex-Pol: Essays 1929-1934, L. Baxandall (Ed.). New York: Random House.

Reich, W. (1945/1970). Sexual revolution: Toward a self-governing character structure. Trans. T. Wolfe. New York: Farrar, Straus and Giroux.

Rich, A. (1980/1986). Compulsory heterosexuality and lesbian existence. In Blood, bread, and poetry (pp. 23-75). New York: Norton.

Roth, P. (1996). Sabbath's theater. New York: Vintage.

Rousseau, J.-J. (1754/1984). Discourse on inequality. Trans. M. Cranston. New York: Penguin. Russell, B. (1929). Marriage and morals. London: George Allen and Unwin.

Santas, G. (1988). Plato and Freud: Two theories of love. Oxford: Blackwell.

Sartre, J.-P. (1943/1956). Being and nothingness. Trans. H. Barnes. New York: Philosophical Library.

Schaff, P. (Ed.) (1892). The principal works of St. Jerome. New York: Christian Literature Publishing Co.

Schopenhauer, A. (1844/1958). The world as will and representation, Vol. 2. Trans. E. Payne. Indian Hills, CO: Falcon's Wing Press.

Scruton, R. (1986). Sexual desire: A moral philosophy of the erotic. New York: Free Press.

Sihvola, J. (2002). Aristotle on sex and love. In M. Nussbaum \& J. Sihvola (Eds.), The sleep of reason: Erotic experience and sexual ethics in ancient Greece and Rome (pp. 200-221). Chicago: University of Chicago Press.

Silverstein, C. (1984). The ethical and moral implications of sexual classification: A commentary. Journal of Homosexuality 9 (4), 29-38.

Soble, A. (1986). Pornography: Marxism, feminism, and the future of sexuality. New Haven, CT: Yale University Press.

Soble, A. (1990). The structure of love. New Haven, CT: Yale University Press.

Soble, A. (1996). Sexual investigations. New York: New York University Press.

Soble, A. (2001/2008). Sexual use. In A. Soble \& N. Power (Eds.), Philosophy of sex (5th ed., pp. 259-288). Lanham, MD: Rowman and Littlefield.

Soble, A. (2002). Pornography, sex, and feminism. Amherst, NY: Prometheus.

Soble, A. (2003). Kant and sexual perversion. Monist 86(1), 57-92. 
Soble, A. (2004). Paraphilia and distress in DSM-IV. In J. Radden (Ed.), The philosophy of psychiatry (pp. 54-63). New York: Oxford University Press.

Soble, A. (2006). Masturbation. In A. Soble (Ed.), Sex from Plato to Paglia: A philosophical encyclopedia (pp. 671-682). Westport, CT: Greenwood.

Soble, A. (2008). The philosophy of sex and love: An introduction (2nd ed.). St. Paul, MN: Paragon House.

Soble, A. (Ed.) (1989/1999). Eros, agape, and philia. St. Paul, MN: Paragon House.

Soble, A. (Ed.) (1997). Sex, love, and friendship. Amsterdam: Rodopi.

Soble, A. (Ed.) (2006). Sex from Plato to Paglia: A philosophical encyclopedia. Westport, CT: Greenwood.

Soble, A., \& Power, N. (Eds.) (2008). The philosophy of sex: Contemporary readings (5th ed.). Lanham, MD: Rowman and Littlefield.

Solomon, R. C., \& Higgins, K. M. (Eds.) (1991). The philosophy of (erotic) love. Lawrence: University Press of Kansas.

Stafford, J. M. (1995). Essays on sexuality and ethics. Solihull, Eng.: Ismeron.

Stewart, R. (Ed.) (1995). Philosophical perspectives on sex and love. New York: Oxford University Press.

Thurber, J., \& White, E. B. (1929/1975). Is sex necessary? Or why you feel the way you do. New York: Harper and Row.

Trevas, R., Zucker, A., \& Borchert, D. (Eds.) (1997). Philosophy of sex and love: A reader. Upper Saddle River, NJ: Prentice-Hall.

Tuana, N., \& Shrage, L. (2003). Sexuality. In H. LaFollette (Ed.), The Oxford handbook of practical ethics (pp. 15-41). Oxford: Oxford University Press.

Twain, M. [S. Clemens] (1876/1936). The adventures of Tom Sawyer. Boston: Walter H. Baker.

Twain, M. [S. Clemens] (1904-1905/2000). The diaries of Adam and Eve. Amherst, NY: Prometheus.

Verene, D. (Ed.) (1972/1995). Sexual love and western morality: A philosophical anthology (2nd ed.). Boston: Jones and Bartlett.

Wojtyla, K. [Pope John Paul II] (1960/1981). Love and responsibility. New York: Farrar, Straus and Giroux. 